\title{
Distal Bile Duct Cancer Pathologic Distant Metastasis TNM Finding v7
}

National Cancer Institute

\section{Source}

National Cancer Institute. Distal Bile Duct Cancer Pathologic Distant Metastasis TNM

Finding v7. NCI Thesaurus. Code C90257.

A pathologic finding about one or more characteristics of distal bile duct cancer, following the rules of the TNM AJCC V7 classification system as they pertain to distant metastases. There is no pathologic M0 for distal bile duct cancer. (from AJCC 7th Ed.) 